\title{
The Australian fruit Illawarra plum (Podocarpus elatus Endl., Podocarpaceae) inhibits telomerase, increases histone deacetylase activity and decreases proliferation of colon cancer cells
}

\author{
Erin L. Symonds ${ }^{1 *}$, Izabela Konczak ${ }^{2}$ and Michael Fenech ${ }^{1}$ \\ ${ }^{1}$ Nutrigenomics and Nutrigenetics, CSIRO Food and Nutritional Sciences, Adelaide, SA 5000, Australia \\ ${ }^{2}$ CSIRO Food and Nutritional Sciences, North Ryde, NSW 1670, Australia \\ (Submitted 10 April 2012 - Final revision received 17 August 2012 - Accepted 20 August 2012 - First published online 15 October 2012)
}

\section{Abstract}

Fruit antioxidants have many health benefits including prevention of cancer development. The native Australian bush fruit Illawarra plum (Podocarpus elatus Endl., Podocarpaceae) has a high content of anthocyanin-rich phenolics, with an antioxidant capacity at levels higher than most fruits. In the present study the molecular mechanisms of the anti-proliferative activity of Illawarra plum on colorectal cancer cells were investigated. Non-tumorigenic young adult mouse colonic (YAMC) cells and tumorigenic human colonic (HT-29) cells were treated with a polyphenolic-rich Illawarra plum extract $(0-1000 \mu \mathrm{g} / \mathrm{ml})$. Illawarra plum had anti-proliferative properties in only the cancer cells, with growth suppressed in a dose- and time-dependent manner. Treatment of HT-29 cells with Illawarra plum extract $(500 \mu \mathrm{g} / \mathrm{ml} ; 24 \mathrm{~h})$ was also associated with a 2 -fold increase in apoptosis, and a cell cycle delay in the $\mathrm{S}$ phase $(P<0 \cdot 01)$. Assessment of biomarkers for DNA damage revealed that plum treatment caused a 93\% down-regulation of telomerase activity $(P<0 \cdot 001)$ and a decrease in telomere length (up to $75 \% ; P<0 \cdot 01$ ). Treatment with Illawarra plum extract also induced morphological alterations to HT-29 cells that were suggestive of induction of autophagy, as the formation of cytoplasmic vacuoles was observed in many cells. This could be induced by the increased (6-fold) histone deacetylase (HDAC) activity $(P<0.001)$ and the trend for increased expression of the class III HDAC sirtuin 1. The present study has shown that Illawarra plum extract is able to reduce the proliferation of colon cancer cells by altering the cell cycle, increasing apoptosis and possibly inducing autophagy. The active ingredients in Illawarra plum may provide an alternative chemoprevention strategy to conventional chemotherapy.

\section{Key words: Colon cancer: Anthocyanins: Autophagy: Histone deacetylase: Proliferation}

Colorectal cancer is a common cancer in Australia, causing approximately 4000 deaths per year ${ }^{(1)}$. Conventional treatment is with cytotoxic drugs; however, these damage the normal tissue and have limitations when the cancer has an increased resistance to chemotherapy. Cancer prevention and treatment by phytochemicals that inhibit the growth of cancers are a possible alternative strategy. Cancers in the gastrointestinal tract are amongst those most responsive to dietary modulation as gastrointestinal cancers can be in direct contact with bioactives present in food.

Generally, the growth of cancer cells exceeds that of normal cells due to malfunctioning of their proliferation and death controls and therefore agents that modulate proliferation and cell death have promise as anti-cancer therapeutics. Epidemiological studies have shown that the presence of phenolic compounds in fruit and vegetables contributes to the maintenance of health (for a review, see Halliwell ${ }^{(2)}$ ). There is a correlation between the total phenolics of fruit and the antioxidant capacity ${ }^{(3)}$. Polyphenols have potent antioxidant activity and play a role in the prevention of diseases such as cancer $^{(4-7)}$, via protecting cells against oxidative damage and therefore preventing the damaging effects of free radicals on $\mathrm{DNA}^{(8)}$. Anthocyanins are an example of phenolic compounds that inhibit cancer cell growth ${ }^{(9)}$. They are one of the main classes of flavonoids and contribute significantly to the antioxidant activities of fruits and vegetables. Anthocyanin-rich berry extracts inhibit the growth of colon cancer cells in vitro ${ }^{(10,11)}$, with two previous studies suggesting little to no cytotoxic effects on non-tumorigenic cells ${ }^{(11,12)}$. The anthocyanidins delphinidin and cyanidin cause apoptosis as well as alterations to the cell cycle in cancer cells ${ }^{(13)}$. Other mechanisms of anti-cancer effects for fruit bioactives include anti-inflammatory properties ${ }^{(14)}$, modulation of gene expression $^{(9,15)}$ and induction of apoptosis ${ }^{(9,10,16)}$.

Abbreviations: CBMN, cytokinesis-block micronucleus; HDAC, histone deacetylase; hTERT, telomerase RT; SIRT1, sirtuin 1; YAMC,

young adult mouse colon.

*Corresponding author: Dr Erin Symonds, fax +61 88303 8896, email erinsymonds@yahoo.com 
Due to their high content of phenolic compounds, most studies investigating anti-cancer properties of fruit have been done with berries; however, native Australian fruits have served as a source of food and medicine for the indigenous population for thousands of years, but limited data on the nutritional and health benefits have been produced ${ }^{(3)}$. The native Australian bush fruit Illawarra plum (Podocarpus elatus Endl., Podocarpaceae) has a high content of anthocyanin-rich phenolics (phenolic and anthocyanin levels are 2.4- and 1.7-fold higher, respectively, than that of blueberry ${ }^{(3,17)}$ ), with an oxygen radical-scavenging ability $146 \%$ of blueberry ${ }^{(17)}$. A previous study showed Illawarra plum to have anti-proliferative activity and cause apoptosis of cancer cells ${ }^{(17)}$. The present study was designed to confirm these investigations, to investigate the underlying molecular mechanisms and to identify the nutrient-genome interactions with colon cancer cells.

\section{Methods}

\section{Chemicals}

All chemicals were purchased from Sigma-Aldrich, unless otherwise stated. The Illawarra plum used throughout these studies was a polyphenolic-rich extract (acidified methanol extraction $^{(3,18)}$, purified twice on an XAD-7HP column and freeze-dried to produce a lyophilised powder) provided by Dr I. Konczak (CSIRO). Illawarra plum has previously been characterised as containing the anthocyanins cyanidin 3-glucoside $(330 \mathrm{mg} / \mathrm{g})$, pelargonidin 3-glucoside $(6.0 \mathrm{mg} / \mathrm{g})$ and delphinidin 3 -glucoside $(1.8 \mathrm{mg} / \mathrm{g})$. It also contains quercetin glucoside $(5 \cdot 8 \mathrm{mg} / \mathrm{g})$ and luteolin $(22.5 \mathrm{mg} / \mathrm{g})^{(17)}$.

\section{Cells and cell culture conditions}

HT-29 human colorectal cancer cells were obtained from the American Type Culture Collection and non-tumorigenic young adult mouse colon (YAMC) ${ }^{(19,20)}$ cells were generously provided by The Ludwig Institute for Cancer Research Ltd. Cell line characterisation was done by microscopically monitoring cell morphology. HT-29 cells were cultured in McCoy's 5A modified medium with $\mathrm{NaHCO}_{3}$, supplemented with 5\% fetal bovine serum (In Vitro Technologies), $1 \%$ penicillin/streptomycin (10 000 units penicillin, $10 \mathrm{mg} / \mathrm{ml}$ streptomycin) and $1 \%$ L-glutamine $(200 \mathrm{~mm})$. Cells were maintained at $37^{\circ} \mathrm{C}$ with $5 \% \mathrm{CO}_{2}$. Cells were split (with trypsin-EDTA) and sub-cultured or seeded into plates when they were at $70-80 \%$ confluency.

YAMC cells were grown under permissive conditions at $33^{\circ} \mathrm{C}$ with $5 \% \mathrm{CO}_{2}$, where the temperature-sensitive simian vacuolating virus 40 (SV40) large $\mathrm{T}$ antigen is active and drives cell proliferation. At higher temperatures the antigen yields an inactive protein and the cells behave as differentiated colonic epithelial cells that undergo apoptosis if they achieve maximal confluence ${ }^{(21)}$. The detailed growth conditions were as follows. Cells were cultured on collagen I-coated flasks at $33^{\circ} \mathrm{C}$ in Roswell Park Memorial Institute (RPMI) 1640 medium supplemented with 5\% fetal bovine serum,
$1 \%$ penicillin/streptomycin (10 000 units penicillin, $10 \mathrm{mg} / \mathrm{ml}$ streptomycin), $1 \%$ L-glutamine (200 mm), 1\% Insulin, Transferrin, Selenium, Sodium Pyruvate (ITS-A) solution (containing $1 \mathrm{~g} / \mathrm{l}$ insulin, $0.55 \mathrm{~g} / \mathrm{l}$ transferrin, $0.67 \mathrm{mg} / \mathrm{l}$ sodium selenite anhydrous) and $5 \mathrm{U} / \mathrm{ml}$ murine recombinant interferon- $\gamma$ (Jomar Diagnostics). When cells reached about $70 \%$ confluence they were transferred to non-permissive conditions. They were seeded on collagen I-coated plates in serum-free and interferon- $\gamma$-free medium, and incubated at $37^{\circ} \mathrm{C}$. They were maintained under these conditions for $48 \mathrm{~h}$ before experimental use.

\section{Effect of Illawarra plum on cell proliferation}

HT-29 cells seeded in ninety-six-well plates were treated with Illawarra plum extract in culture medium $(0-2000 \mu \mathrm{g} / \mathrm{ml})$ for $1-48 \mathrm{~h}$, followed by the 3-(4,5-dimethylthiazol-2-yl)-2, 5-diphenyltetrazolium bromide (MTT) assay ${ }^{(22)}$ to assess cell proliferation. YAMC cells were treated with Illawarra plum extract $(0-1000 \mu \mathrm{g} / \mathrm{ml})$ for $24 \mathrm{~h}$ to assess the effect on non-tumorigenic cells. Briefly, treatments were removed from the cells and $500 \mu \mathrm{g} / \mathrm{ml}$ MTT was added. Following $2.5 \mathrm{~h}$ incubation, $10 \%$ SDS in $10 \mathrm{~mm}-\mathrm{HCl}$ was added to solubilise the formazan crystals. The number of surviving cells was directly proportional to the level of the formazan product created, which was quantified with a spectrophotometer (SpectraMax 250; Molecular Devices), with absorbance measured at $600 \mathrm{~nm}$ (reference wavelength $650 \mathrm{~nm}$ ). Optical density values from 'blank' wells (that contained no cells but had still been treated with the varying concentrations of plum) were subtracted from the results. Cell growth with treatment was expressed as a percentage of the non-treated cells.

\section{Effect of Illawarra plum on the cell cycle}

HT-29 cells were treated with Illawarra plum extract $(0-1000 \mu \mathrm{g} / \mathrm{ml})$ for $24 \mathrm{~h}$, then released from the wells with TrypLe Express (Gibco BRL). Wells were rinsed with PBS and cells were centrifuged at $410 \boldsymbol{g}$ for $5 \mathrm{~min}$. The supernatant fraction was removed and cells were re-suspended in PBS and cold $70 \%$ ethanol was added. Cells were stored at $-20^{\circ} \mathrm{C}$ until analysed for cell cycle on a flow cytometer (BD FACSCalibur $^{\mathrm{TM}}$; BD Biosciences). For analysis, cells were centrifuged and rinsed with PBS, followed by re-suspension of the cell pellet in $1 \mathrm{ml}$ propidium iodide stain ( $2 \%$ propidium iodide, $0 \cdot 1 \%$ Triton X-100 and $4 \mathrm{mg}$ Rnase, all in PBS) in the dark for $1 \mathrm{~h}$ at room temperature. Cells were run through the flow cytometer and a total of 15000 events per sample were captured. The proportion of cells in G0/G1, S, G2/M and pre-G0/G1 were determined as previously described ${ }^{(23)}$.

\section{Biomarkers of DNA damage}

To assess the effect of Illawarra plum extract on cell morphology and markers of DNA damage, the cytokinesis-block micronucleus (CBMN) cytome assay was performed as previously described for lymphocytes ${ }^{(24)}$ but with some minor modifications. HT-29 cells were treated with Illawarra plum 
extract $(0-1000 \mu \mathrm{g} / \mathrm{ml})$ for $24 \mathrm{~h}$. Treatments were removed and $4.5 \mu \mathrm{g} / \mathrm{ml}$ cytochalasin-B was added to the cells with media for a further $24 \mathrm{~h}$. Cells were then released from wells with TrypLe Express, followed by suspension in media. Cells $(100 \mu \mathrm{l})$ were added to a cytospin cup and centrifuged (600 rpm, $5 \mathrm{~min}$ ) on to glass slides. Following $10 \mathrm{~min}$ air-drying, cells were fixed in methanol and stained with the Diff Quik staining kit (Lab Aids Pty Ltd). Cells were scored for damage with a $100 \times$ objective with oil (Leica DM LB2 with Spot software; PathTech) as previously described ${ }^{(24)}$. Briefly, cytotoxicity and cytostasis was assessed by determining the number of necrotic and apoptotic cells, as well as the number of dividing cells (mono-, bi- and multinucleated) (average of 600 cells per slide were assessed). DNA damage was scored by determining the number of binucleated cells (out of $>500$ binucleated cells) containing micronuclei, nucleoplasmic bridges and nuclear buds ${ }^{(24)}$. Other abnormal cellular and nuclear morphological anomalies unique to the present study were noted.

To further assess morphological changes, slides (prepared as above) were stained with Feulgen and light green stain. Slides were placed in $5 \mathrm{M}-\mathrm{HCl}$ for $30 \mathrm{~min}$, then Schiff's reagent for $60 \mathrm{~min}$, then counter-stained with $0 \cdot 2 \%$ light green $(\mathrm{w} / \mathrm{v})$ for $30 \mathrm{~s}$. Slides were viewed with a $100 \times$ objective with oil under transmitted light microscopy (the nuclei are magenta in color, whereas the cytoplasm is pale blue/green) and fluorescent microscopy with a far-red filter (DNA appears bright red).

DNA damage was also assessed by measuring telomere length following a quantitative real-time PCR protocol ${ }^{(25)}$. HT-29 cells were treated with Illawarra plum extract $(0-1000 \mu \mathrm{g} / \mathrm{ml})$ for $24 \mathrm{~h}$. DNA was isolated using the Qiagen Blood and Tissue Kit (Qiagen) according to the manufacturer's instructions and quantified (NanoDrop Technologies). For each DNA sample, real-time PCR was performed using primers for telomere length analysis and for 36b4 (single copy gene, Table 1), with SYBR (Green PCR Master Mix (Applied Biosystems) using the Applied Biosystems 7300 Real-Time PCR System. A standard curve of $1.18 \times 10^{3}-1.18 \times 10^{8} \mathrm{~kb}$ of telomere sequence was included. The parameter threshold was defined as the fractional cycle number at which the fluorescence passed a fixed threshold above the baseline value (cycle threshold; $\mathrm{C}_{\mathrm{T}}$ ). Telomere length was determined from the telomere standard curve, while genome copy numbers were determined from an established standard curve $^{(25)}$. Absolute telomere length was expressed as $\mathrm{kb}$ telomere/genome.

To assess if Illawarra plum extract was having any affect on histone structure, the histone deacetylase (HDAC) activity assay was performed. HT-29 cells were treated with Illawarra plum extract $(0-500 \mu \mathrm{g} / \mathrm{ml})$ for $24 \mathrm{~h}$. The Fleur de Lys HDAC fluorometric assay (BIOMOL International, through Sapphire Bioscience) was used according to the manufacturer's instructions. Results were expressed as relative fluorescence units.

\section{Gene expression}

To determine the effect of Illawarra plum extract treatment on expression of genes related to HDAC activity, telomere length and apoptosis, HT-29 cells were treated with extract $(0-500 \mu \mathrm{g} / \mathrm{ml})$ for $24 \mathrm{~h}$. Total RNA was extracted from the cells using Trizol (Invitrogen) according to the manufacturer's instructions, and quantity and quality of RNA were assessed (NanoDrop). RNA was reversed transcribed using the SuperScript III First-strand synthesis system (Invitrogen) and realtime PCR was performed with Taqman master mix and primers for sirtuin 1 (SIRT1; Hs01009005_m1), telomerase RT (hTERT; Hs00972656_m1) and tumour protein p53 (TP53; Hs01034249_m1) (Applied Biosystems). Amplification of glyceraldehyde-3-phosphate dehydrogenase (GAPDH; Hs02758991_g1) (Applied Biosystems) was included as an endogenous control. Relative mRNA expression levels were calculated with the formula $2^{-\Delta \Delta C T}$ where the $C_{T}$ of the target gene was normalised to GAPDH expression and expressed relative to the control group ${ }^{(26)}$.

\section{Statistical analysis}

All studies were conducted in triplicate and repeated on at least three independent occasions. Data are expressed as mean values with their standard errors. Analysis was with an unpaired Student's $t$ test, or a one-way ANOVA with the Holm-Sidak post hoc test when statistical significance was found $(P<0.05)$. Statistical analysis was performed with Sigmaplot 11.0 (Systat Software, Inc.).

\section{Results}

\section{Effect of Illawarra plum on cell proliferation}

Cell proliferation of HT-29 cells was slightly increased with low concentrations of Illawarra plum extract, but decreased with higher concentrations in a time- and dose-dependent manner $(P<0.001$; Fig. 1(a)). The concentration of extract required to cause $50 \%$ growth inhibition was 4001, 1479 and $1318 \mu \mathrm{g} / \mathrm{ml}$ for 1,24 and $48 \mathrm{~h}$ of treatment, respectively. Treatment of YAMC cells with Illawarra plum extract did not significantly decrease their viability, but promoted growth at the highest concentrations assessed $(P<0 \cdot 05$; Fig. 1(b)).

Table 1. PCR primers

\begin{tabular}{ll}
\hline Primer & Sequence \\
\hline Telomere forward primer & $5^{\prime}$ CGGTTTGTTTGGGTTTGGGTTTGGGTTTGGGTTTGGGTT 3' \\
Telomere reverse primer & $5^{\prime}$ GGCTTGCCTTACCCTTACCCTTACCCTTACCCTTACCCT 3' \\
36B4 forward primer & $5^{\prime}$ CCCATTCTATCATCAACGGGTACAA 3' \\
36B4 reverse primer & $5^{\prime}$ CAGCAAGTGGGAAGGTGTAATCC 3' \\
\hline
\end{tabular}



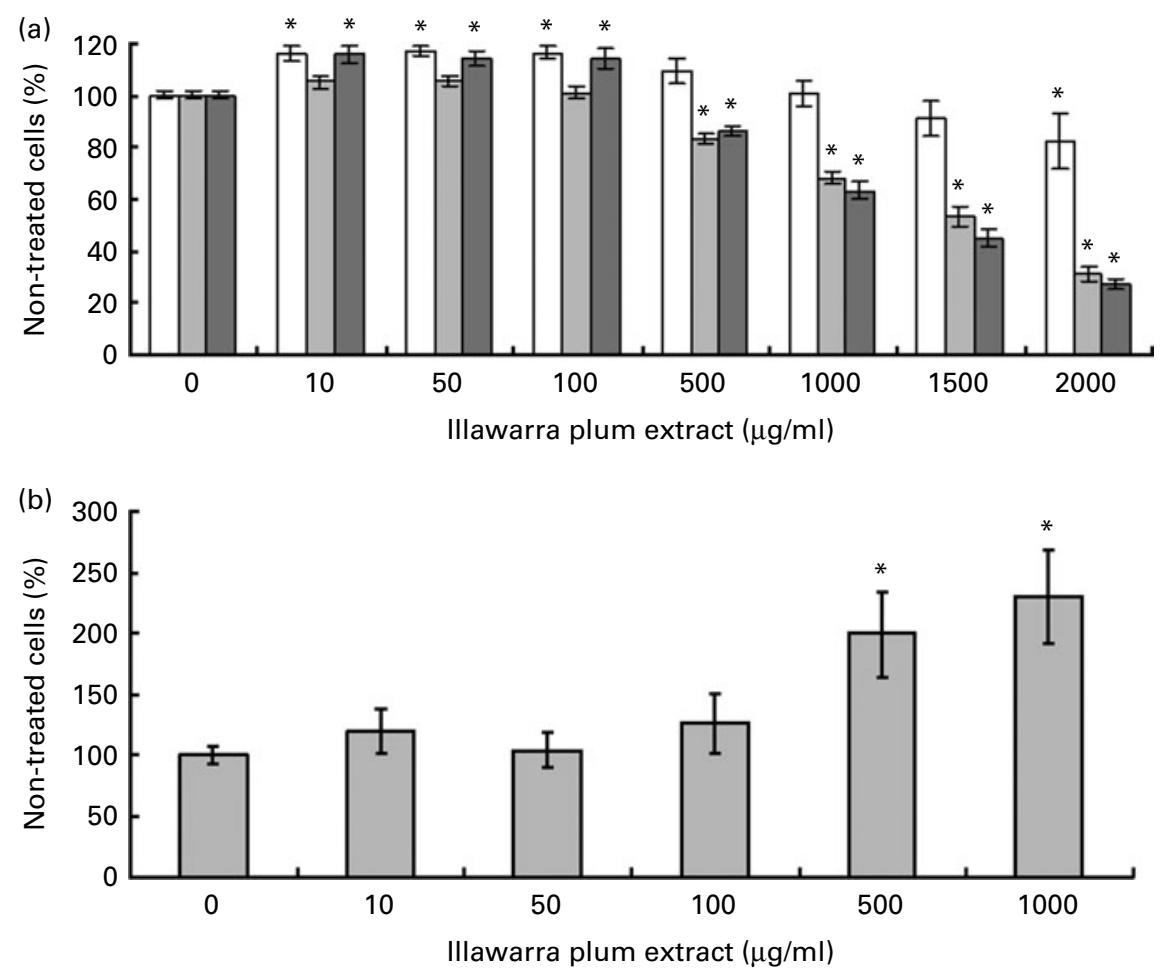

Fig. 1. Effect of Illawarra plum (Podocarpus elatus Endl., Podocarpaceae) extract on cell growth/viability of (a) tumorigenic human colon HT-29 cells following $1 \mathrm{~h}$ $(\square), 24 \mathrm{~h} \mathrm{( \square )} \mathrm{and} 48 \mathrm{~h} \mathrm{( \square )} \mathrm{of} \mathrm{treatment;} \mathrm{and} \mathrm{on} \mathrm{(b)} \mathrm{non-tumorigenic} \mathrm{young} \mathrm{adult} \mathrm{mouse} \mathrm{colonic} \mathrm{(YAMC)} \mathrm{cells} \mathrm{following} 24 \mathrm{~h}$ of treatment. Data are means, with standard errors represented by vertical bars. ${ }^{*}$ Mean value was significantly different from that of non-treated cells (at the same time point) $(P<0.05)$.

\section{Effect of Illawarra plum on the cell cycle}

Treatment of Illawarra plum extract caused a significant dosedependent decrease in the population of cells in the G0/G1 phase of the cell cycle and an increase in the number in the $S$ phase $(P<0.001 ;$ Fig. 2). There was also an increase in the pre-G0/G1 peak that is considered to be apoptotic cells $(P<0 \cdot 001$; Fig. 2).

\section{Markers of cytotoxicity, cytostasis and DNA damage}

Microscopic analysis of HT-29 cells following the CBMN cytome assay showed that increasing concentrations of treatment with Illawarra plum extract caused a decrease in the number of proliferating cells. The nuclear division index $(=($ mononucleated $+($ binucleated $\times 2)+($ multinucleated $\times 3))$ total viable cells) significantly decreased from 1.23 (SEM 0.02) in control cells to $1 \cdot 12$ (SEM $0 \cdot 01$ ) in cells treated with $1000 \mu \mathrm{g} / \mathrm{ml}$ Illawarra plum extract $(P<0 \cdot 01)$. There was also a dose-dependent increase in cytotoxicity, with a significant increase in the proportion of apoptotic and necrotic cells (Fig. 3(a); $P<0 \cdot 01$ ).

Biomarkers of DNA damage were only quantified for nontreated and $100 \mu \mathrm{g} / \mathrm{ml}$ extract-treated cells, due to higher levels of plum reducing the number of binucleated cells to a level too low for accurate analysis. Illawarra plum extract increased the number of binucleated cells containing micronuclei, nucleoplasmic bridges and nuclear buds by approximately 2-fold ( $P<0.05$; Fig. 3(b)). It was also observed that following $24 \mathrm{~h}$ treatment with Illawarra plum extract, many of the cell cytoplasms contained vacuoles (Fig. 3(d)), and a high proportion of the nuclear buds were being engulfed by these vacuoles, suggesting autophagy ${ }^{(27)}$

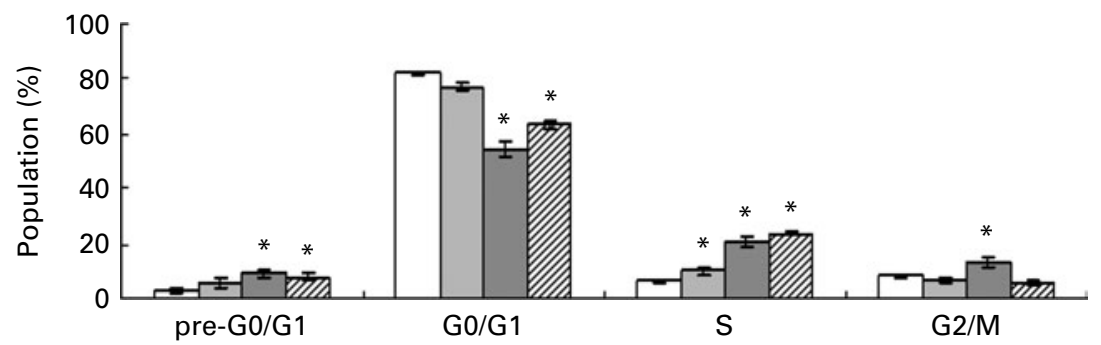

Fig. 2. Cell cycle of tumorigenic human colon HT-29 cells following $24 \mathrm{~h}$ treatment with 0 ( $\square$ ), 100 ( $\square$ ), 500 ( $\square$ ) and $1000 \mu \mathrm{g} / \mathrm{ml}$ ( $\square)$ Illawarra plum (Podocarpus elatus Endl., Podocarpaceae) extract. Data are means, with standard errors represented by vertical bars. ${ }^{*}$ Mean value was significantly different from that of non-treated cells $(P<0.05)$. 

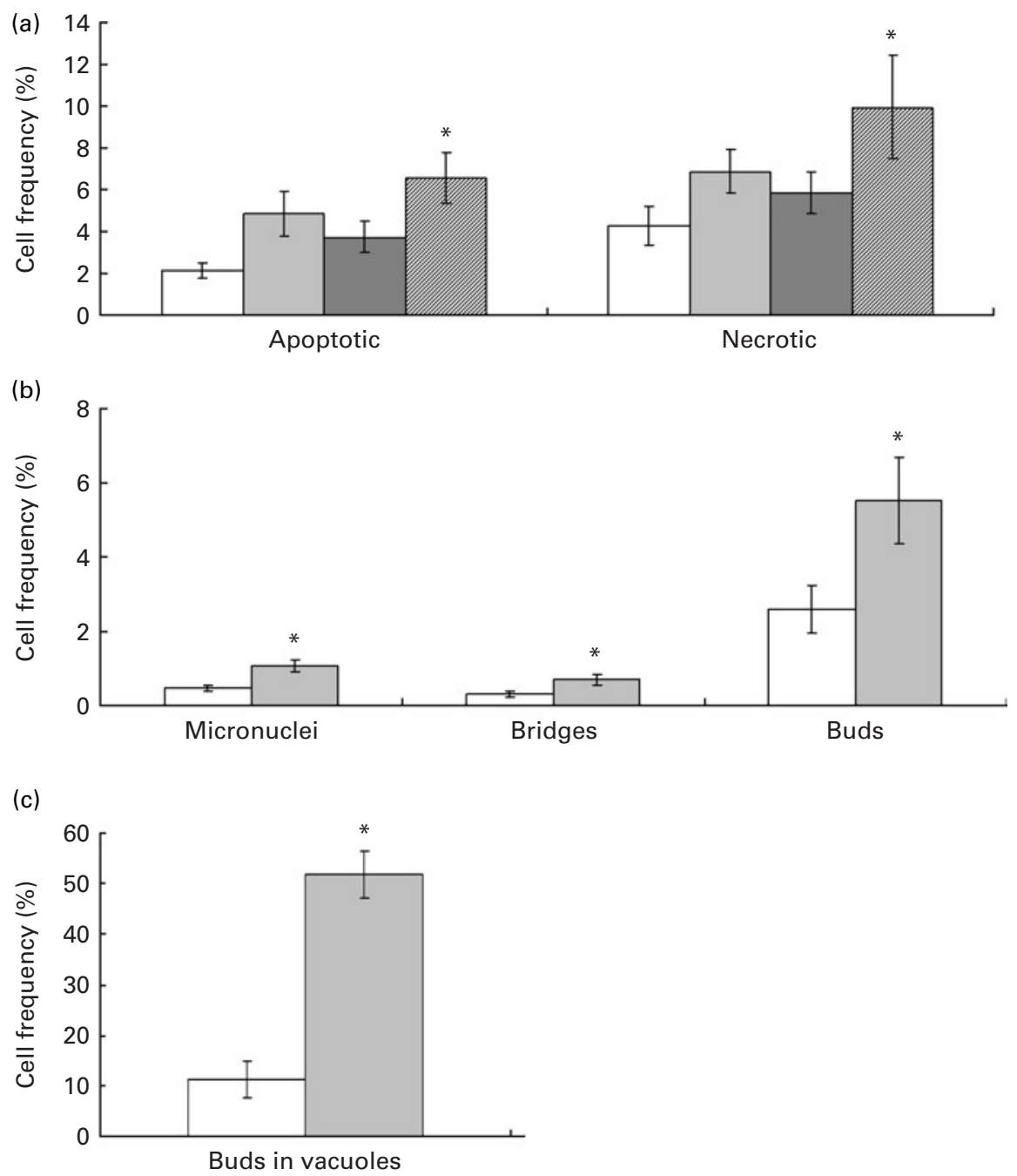

(d)

(e)
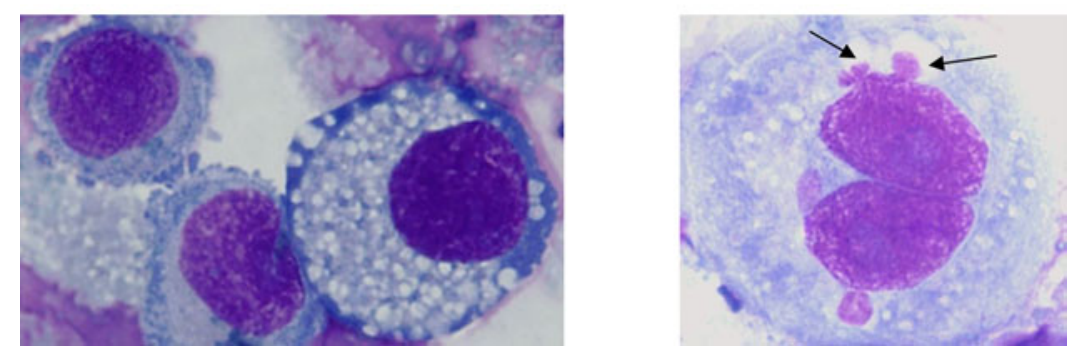

Fig. 3. The cytokinesis-block micronucleus cytome assay performed on tumorigenic human colon HT-29 cells following various treatment concentrations with Illawarra plum (Podocarpus elatus Endl., Podocarpaceae) extract. (a) Proportion of apoptotic and necrotic cells following $24 \mathrm{~h}$ treatment with 0 ( $\square$ ), 100 ( $\square$ ), 500 ( $\square$ ) and $1000 \mu \mathrm{g} / \mathrm{ml}(\mathbb{E})$ Illawarra plum extract. (b) Proportion of micronuclei, nucleoplasmic bridges and nuclear buds within binucleated cells, and (c) nuclear buds being engulfed by vacuoles following $24 \mathrm{~h}$ treatment with $0(\square)$ and $100 \mu \mathrm{g} / \mathrm{ml}(\square)$ Illawarra plum extract. (d) An example of cell cytoplasm containing vacuoles (stained with Diff Quik, $1000 \times$ magnification). (e) An example of nuclear buds being engulfed by vacuoles $(\rightarrow)$. Cells were stained with Diff Quik $(1000 \times$ magnification). Data are means, with standard errors represented by vertical bars. ${ }^{*}$ Mean value was significantly different from that of non-treated cells $(P<0.05)$. (A colour version of this figure can be found online at $h$ ttp://www.journals.cambridge.org/bjn).

(Fig. 3(e)). In the plum extract-treated cells there was a 4.5 -fold increase in the number of nuclear buds within vacuoles compared with non-treated cells (Fig. 3(c); $P<0 \cdot 0001$ ).

Treatment with Illawarra plum extract also caused other morphological changes. With increasing concentrations of plum extract, there was an increase in the proportion of cells that had a shrunken/compacted nucleus, an intense staining colour and a greatly reduced cytoplasmic volume (Fig. 4(a)-(d)). The nuclear diameter was significantly less than that of the morphologically normal mononucleated cells (9.2 (sem 0.1) v. 15.1 (sEm 0.2) $\mu \mathrm{m} ; P<0 \cdot 001)$. The affected cells all had condensed nuclei, but were not only in the mononucleus form: on average $84 \%$ were mononucleated, $13 \%$ were binucleated and 3\% were undergoing apoptosis. 


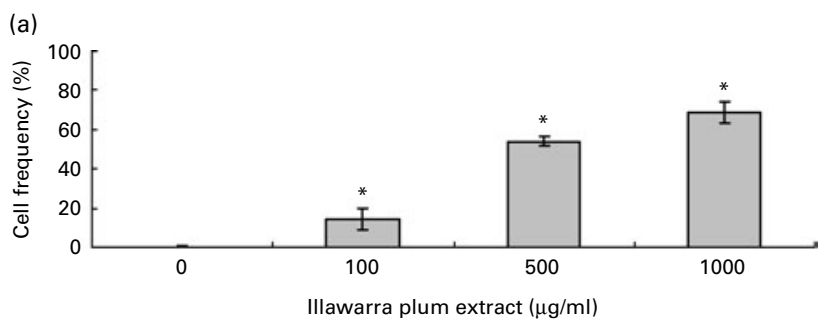

(b)

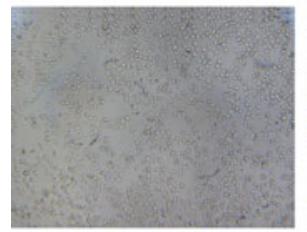

(c)

(d)

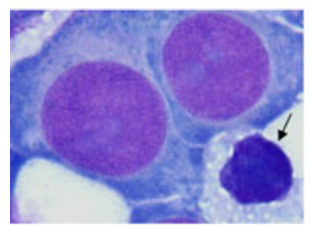

(e)

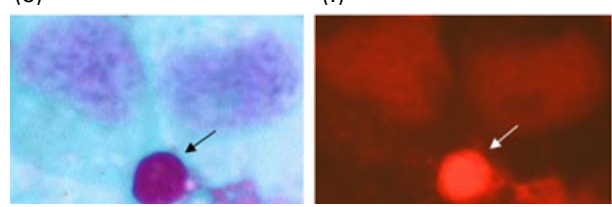

Fig. 4. The cytokinesis-block micronucleus cytome assay performed on tumorigenic human colon HT-29 cells following various treatment concentrations with Illawarra plum (Podocarpus elatus Endl., Podocarpaceae) extract. (a) Proportion of cells with a shrunken morphology. Data are means, with standard errors represented by vertical bars. ${ }^{*}$ Mean value was significantly different from that of non-treated cells $(P<0.05)$. Morphology of cells under a light inverted microscope $(100 \times$ magnification) untreated (b) or treated (c) with $500 \mu \mathrm{g} / \mathrm{ml}$ Illawarra plum extract. (d) Examples of cells with intense staining and shrunken nuclei (stained with Diff Quik, 1000x magnification; showing affected cells; $\rightarrow$ ). Example of healthy cells and a shrunken cell under (e) transmitted light microscopy and (f) fluorescent microscopy (stained with Feulgen and light green stain, $1000 \times$ magnification; showing affected cells; $\rightarrow$ ). (A colour version of this figure can be found online at http://www.journals.cambridge.org/bjn).

When stained with Feulgen and light green, these cells had a more intense stain (the DNA being stained) compared with cells with a normal morphology (Fig. 4(e) and (f)).

Due to the appearance of condensed nuclei of HT-29 cells with Illawarra plum extract treatment, it was investigated whether this was due to increased HDAC activity. Analysis showed that Illawarra plum treatment caused a dosedependent increase in HDAC activity (Fig. 5(a); $P<0.001$ )

Telomere length following treatment with Illawarra plum extract was assessed as another marker of DNA damage. It was found to decrease with increasing concentrations of plum extract, becoming significant following $24 \mathrm{~h}$ of $1000 \mu \mathrm{g} / \mathrm{ml}$ treatment (Fig. 5(b); $P<0.005$ ).

\section{Gene expression}

Illawarra plum extract treatment of HT-29 cells caused a significant decrease in hTERT expression (Fig. 5(c); $P<0.001$ ) and a trend for an increase in SIRT1 expression (Fig. 5(c); $P=0.06)$. Expression of TP53 was not significantly altered (Fig. 5(c); $P>0.05$ ).

\section{Discussion}

Disruptions to the normal regulation of cell division and death are underlying mechanisms of the development of cancer. There are a number of strategies that have been investigated to combat the molecular changes with cancer development; however, in the present study we focused on the effects of a polyphenolic-rich fruit extract on proliferation and apoptosis controlled at the genome level. The success of cancer therapies relies on the extent of their ability to induce death of tumour cells while allowing survival of healthy cells. Illawarra plum extract decreased proliferation in the HT-29 cells, but not in the non-tumorigenic YAMC cells. The decreased proliferation in cancer cells was via changes to the cell cycle, and by decreased gene expression of hTERT which was associated with a decrease in cell telomere length. Illawarra plum treatment of HT-29 cells also increased apoptosis and caused other genome changes including increased numbers of biomarkers for genomic damage, condensed nuclei via increased HDAC activity, and an increased population of cells containing cytoplasmic vacuoles, suggestive of autophagy.

Illawarra plum extract decreased cell proliferation in HT-29 cells, but promoted proliferation in YAMC cells. Whilst the mechanisms underlying the enhanced proliferation in the YAMC cells with the higher concentrations of extract are currently unknown, an inhibition of proliferation of HT-29 cells has been previously found with Illawarra plum extract ${ }^{(17)}$ as well as with other phenolic-rich fruit extracts ${ }^{(9,10,16)}$. Inhibition of proliferation is thought to be correlated with anthocyanin content of the fruit ${ }^{(9,16)}$, of which Illawarra plum has high levels. The dose-dependent decrease in cell viability would have been contributed to by the increased apoptosis and necrosis, and alterations to the cell cycle that was observed following plum treatment. Plum extract decreased the number of cells in the G0/G1 phase and increased those in the $\mathrm{S}$ phase. Phenolic-rich extracts and anthocyanins have also been shown to decrease the proportion of cells in the G0/G1 phase ${ }^{(13)}$ and cause cell cycle arrest in the $S$ phase ${ }^{(28)}$. The accumulation in the $S$ phase suggests a block in the transition from $S$ to $G 2$ phase, which would cause an overall delay in the cell cycle and a decrease in cell proliferation. Inhibition of abnormal cell cycle progression via modulation of cell cycle progression is an important strategy for chemoprevention as well as chemotherapy ${ }^{(29)}$. An accumulation of cells within a certain phase of the cell cycle can improve cancer treatment options, for example, cells synchronised in the $\mathrm{S}$ and $\mathrm{G} 2 / \mathrm{M}$ phases are more sensitive to doxorubicin (an anti-tumour antibiotic) than cells in the G1 phase ${ }^{(30)}$.

In addition to changes in the cell cycle, the decreased cell proliferation could be contributed to by changes in telomere length. Telomeres are maintained by telomerase, a ribonucleoprotein enzyme that includes a RT component (hTERT) and a 
(a)

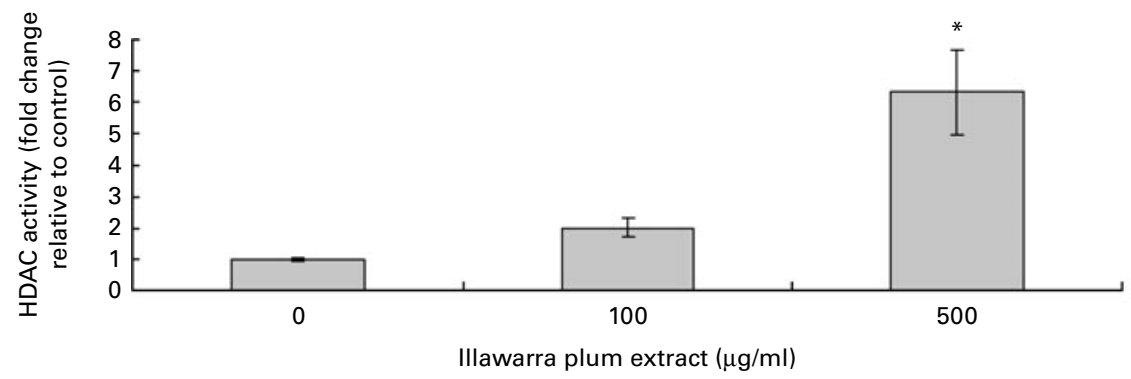

(b)

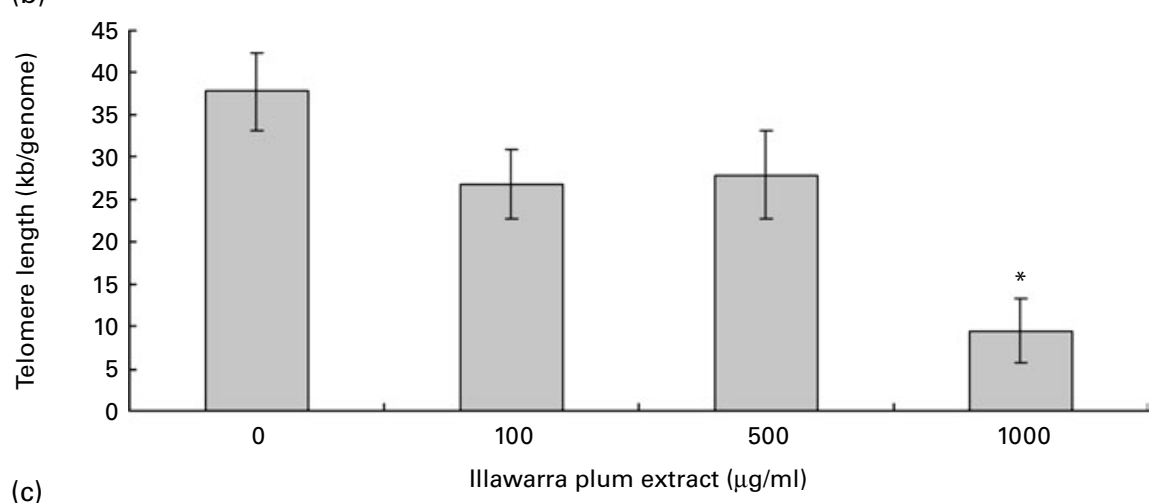

(c)

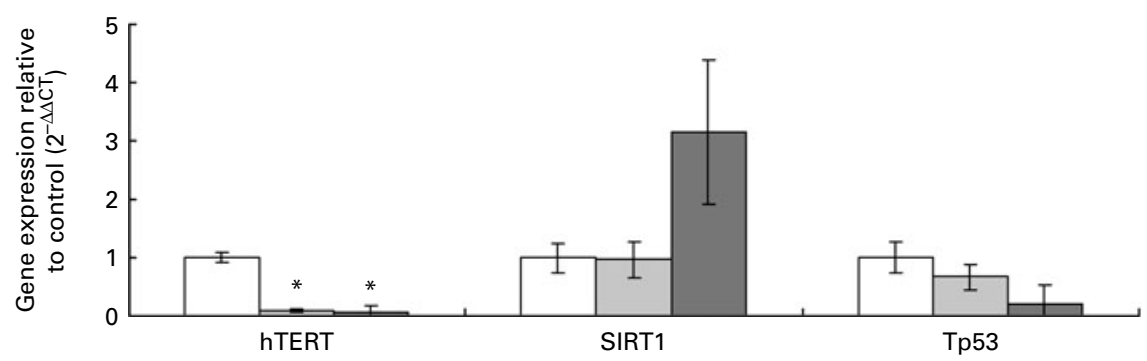

Fig. 5. Effect of Illawarra plum (Podocarpus elatus Endl., Podocarpaceae) on biomarkers of nuclear changes. (a) Histone deacetylase (HDAC) activity and (b) telomere length of tumorigenic human colon HT-29 cells following treatment with various concentrations of Illawarra plum extract. (c) Expression of related genes: telomerase RT (hTERT), sirtuin 1 (SIRT1) and tumour protein p53 (Tp53) following treatment with 0 ( $\square$ ), 100 ( $\square$ ) or $500 \mu \mathrm{g} / \mathrm{ml}$ (口) Illawarra plum extract. Data are means, with standard errors represented by vertical bars. Values are expressed relative to control values. * Mean value was significantly different from that of non-treated cells $(P<0.05)$.

RNA template component ${ }^{(31)}$. In tumour cells, telomerase is highly activated which can lead to unlimited proliferation; therefore relatively new research involves the screening of natural products with telomerase inhibitor activity as potential anti-cancer agents. Treatment with Illawarra plum extract caused a decrease in both hTERT expression and in telomere length. Other plant bioactives have also shown promise at inhibiting telomerase activity ${ }^{(32)}$. Inhibition of telomerase results in telomere shortening, repressed proliferation, and an altered cell cycle, leading to apoptosis ${ }^{(33)}$. Therefore repression of telomerase is an early event in the apoptotic cascade; however, it appears that telomere length must first decrease to a critical length to induce apoptosis. In addition, a decrease in telomere length beyond a critical point could also drive the cells into senescence ${ }^{(34)}$, contributing to the lower cell proliferation found in the present study.

Apoptosis is a form of programmed cell death and is a major mechanism for cancer suppression ${ }^{(16)}$. Treatment with
Illawarra plum extract for $24 \mathrm{~h}$ caused a significant increase in apoptosis, with concordance in results between the two measuring techniques applied - microscopy with the CBMN cytome assay and flow cytometry. Many studies have not quantified apoptosis as they have used the DNA fragmentation method to assess for apoptosis; but, overall, findings suggest that anthocyanin-rich extracts increase levels of apoptosis in cancer cell lines ${ }^{(9,16)}$. The increase in apoptosis induced by Illawarra plum extract was independent of $\mathrm{p} 53$, as there was no significant change in p53 expression, and HT-29 cells express a mutant $\mathrm{p} 53$ that is inactive.

The present study also found that plum treatment resulted in high numbers of cells with altered morphology. These cells were found to represent almost $70 \%$ of the cell population following treatment with $1000 \mu \mathrm{g} / \mathrm{ml}$ Illawarra plum extract. These were not necrotic cells, as the two could be distinguished microscopically with the CBMN cytome assay. Even though they had condensed nuclei and shrunken 
cytoplasm, these cells still appeared to be viable, and were observed to be in the same stages of growth as the nonaffected cells (i.e. equivalent numbers found to be monoand binucleated). Most of these cells had high numbers of cytoplasmic vacuoles, possibly indicative of autophagy, a form of cell death with its main feature being the engulfing of cytoplasmic fractions followed by their degradation ${ }^{(35)}$. Starvation is an initiating condition of autophagy, as this will be triggered to recover precursor molecules, limiting the energetic expense of resynthesis. It is possible that the addition of high levels of plum extract in the cell culture media induced a 'starvation' or energy restriction mimetic condition such as that previously reported with resveratrol which also promotes autophagy ${ }^{(36)}$. A number of studies have now shown that under starvation, SIRT1 expression increases ${ }^{(37)}$ and that SIRT1 activity is necessary for starvation-induced autophagy $^{(38)}$. In the present study we observed a trend for an increase in SIRT1 expression with Illawarra plum treatment.

The cells with morphological alterations were also shown to have an intensely stained nucleus. Whilst the increased vacuoles suggest autophagy, a condensed nucleus might allude to a change to histone binding. We investigated this by measuring HDAC activity. Potential anti-cancer agents are often investigated for their ability to be HDAC inhibitors, as it is hypothesised that inhibitors should reactivate tumour suppressor genes that are silenced during neoplastic development. Following plum treatment, however, there was a dose-dependent increase in HDAC activity. It is possible that an increase in HDAC activity may be silencing the genes required for tumour progression ${ }^{(39)}$, and that loss of acetylation may suppress genes associated with cell cycle progression $^{(40)}$. Other natural agents (such as the bile acid ursodeoxycholic acid ${ }^{(39)}$ ) increase HDAC activity and induce apoptosis in cancer cells. Interestingly, treatment with ursodeoxycholic acid caused other results comparable with our findings including a low level of apoptosis, inhibition of telomerase activity, decreased proliferation, as well as morphological changes of flattened vacuolated structures in approximately $75 \%$ of cells ${ }^{(39)}$.

The CBMN cytome assay with microscopic analysis also showed a decrease in proliferation, with the number of binucleated cells decreasing with increasing concentrations of Illawarra plum. This supports the idea of cytostasis which could be induced by Illawarra plum decreasing telomerase expression and pushing cells into senescence or apoptosis. In addition to this, the CBMN cytome assay showed that Illawarra plum extract caused an increase in micronuclei, nucleoplasmic bridges and nuclear buds, which are all biomarkers for genotoxic damage and chromosomal instability (for a review, see Fenech et al. ${ }^{(41)}$ ). Following treatment it was also observed that many of the nuclear buds were associated with vacuoles. A 'starvation' condition, that may have occurred with plum treatment, has also been found to cause vesicles containing part of the nucleus to pinch off into vacuoles $^{(27)}$. This has been termed 'piecemeal microautophagy of the nucleus' and is likely to be what we observed with the nuclear buds in vacuoles following Illawarra plum extract treatment. Additionally, the increase in nuclear budding from plum treatment may have been associated with the accumulation of cells in the $S$ phase, as during this part of the cell cycle amplified DNA is localised to the periphery of the nucleus and is eliminated via nuclear buds ${ }^{(42)}$. It has been hypothesised that nuclear budding is a mechanism to eliminate excess chromosomes or unresolved DNA repair complexes (for a review, see Fenech et al. ${ }^{(41)}$ ), indicating DNA repair or a nuclear housekeeping process. Shimizu et al. ${ }^{(43)}$ also showed that induction of nuclear budding by hydroxyurea promotes the elimination of amplified oncogenes in cancer cells; whether a similar effect is induced by Illawara plum extract remains to be tested.

The results from the present study on the effects of Illawarra plum on colon cancer cells (suppression of cell proliferation, cell cycle arrest, and induction of apoptosis) are all positive findings for chemopreventive and anti-tumour activity, and are likely to be driven by the high phenolic content and antioxidant capacity of Illawarra plum. An agent that can target the multiple biochemical pathways that are involved in the development of cancer has many advantages. In conclusion, the results from the present study encourage further studies to investigate the chemotherapeutic effects of Illawarra plum using in vivo models.

\section{Acknowledgements}

E. L. S. was supported by a CJ Martin post-doctoral fellowship (salary) awarded by the National Health and Medical Research Council of Australia (no. 357702). The research project received no specific grant from any funding agency in the public, commercial or not-for-profit sectors. E. L. S., I. K. and M. F. designed the research; I. K. provided methodology and essential reagents; E. L. S. conducted the research; E. L. S. and M. F. analysed the data; E. L. S. wrote the paper and had primary responsibility for final content. All authors read and approved the final manuscript. The authors have no conflicts of interest.

\section{References}

1. Australian Institute of Health and Welfare. (2011) Australian Cancer Incidence and Mortality (ACIM) books. http:// www.aihw.gov.au/acim-books/ (accessed January 2012).

2. Halliwell B (2007) Dietary polyphenols: good, bad, or indifferent for your health? Cardiovasc Res 73, 341-347.

3. Netzel M, Netzel G, Tian Q, et al. (2007) Native Australian fruits - a novel source of antioxidants for food. Innov Food Sci Emerg Tech 8, 339-346.

4. Di Domenico F, Foppoli C, Coccia R, et al. (2012) Antioxidants in cervical cancer: chemopreventive and chemotherapeutic effects of polyphenols. Biochim Biophys Acta 1822, 737-747.

5. George J, Singh M, Srivastava A, et al. (2011) Resveratrol and black tea polyphenol combination synergistically suppress mouse skin tumors growth by inhibition of activated MAPKs and p53. PLoS One 6, e23395.

6. Kang S, Seeram N, Nair M, et al. (2003) Tart cherry anthocyanins inhibit tumor development in $\mathrm{APC}(\mathrm{min})$ mice and reduce proliferation of human colon cancer cells. Cancer Lett 194, 13-19. 
7. Stoner G, Chen T, Kresty L, et al. (2006) Protection against esophageal cancer in rodents with lyophilized berries: potential mechanisms. Nutr Cancer 54, 33-46.

8. Rice-Evans C, Miller N \& Paganga G (1996) Structureantioxidant activity relationship of flavonoids and phenolic acids. Free Radic Biol Med 20, 933-956.

9. Wu Q, Koponen J, Mykkänen H, et al. (2007) Berry phenolic extracts modulate the expression of $\mathrm{p} 21^{\mathrm{WAF} 1}$ and Bax but not Bcl-2 in HT-29 colon cancer cells. J Agric Food Chem 55 , $1156-1163$.

10. Yi W, Fischer J, Krewer G, et al. (2005) Phenolic compounds from blueberries can inhibit colon cancer cell proliferation and induce apoptosis. J Agric Food Chem 53, 7320-7329.

11. Malik M, Zhao C, Schoene N, et al. (2003) Anthocyanin-rich extract from Aronia meloncarpa E. induces a cell cycle block in colon cancer but not normal colonic cells. Nutr Cancer 46, 186-196.

12. Zhao C, Giusti M, Malik M, et al. (2004) Effects of commercial anthocyanin-rich extracts on colonic cancer and nontumorigenic colonic cell growth. J Agric Food Chem 52, 6122-6128.

13. Lazzè M, Savio M, Pizzala R, et al. (2004) Anthocyanins induce cell cycle perturbations and apoptosis in different human cell lines. Carcinogenesis 25, 1427-1433.

14. Tan A, Houc D, Konczak I, et al. (2011) Native Australian fruit polyphenols inhibit COX-2 and iNOS expression in LPS-activated murine macrophages. Food Res Int 44 , 2362-2367.

15. Boivin D, Blanchette M, Barrette S, et al. (2007) Inhibition of cancer cell proliferation and suppression of TNF-induced activation of $\mathrm{NF \kappa B}$ by edible berry juice. Anticancer Res 27, 937-948.

16. Seeram N, Adams L, Zhang Y, et al. (2006) Blackberry, black raspberry, blueberry, cranberry, red raspberry, and strawberry extracts inhibit growth and stimulate apoptosis of human cancer cells in vitro. J Agric Food Chem 54, 9329-9339.

17. Konczak I, Zabaras D, Xiao D, et al. (2008) Screening native Australian fruits for health-promoting properties. Anti-proliferative and pro-apoptotic activity of Illawarra plum. J Clin Biochem Nutr 43, 543-547.

18. Terahara N, Koncak-Islam I, Nakatni M, et al. (2000) Anthocyanins in callus induced from purple storage root of Ipomoea batatas L. Phytochemistry 54, 919-922.

19. Jat P, Noble M, Ataliotis P, et al. (1991) Direct derivation of conditionally immortal cell lines from an H-2Kb-tsA58 transgenic mouse. Proc Natl Acad Sci U S A 88, 5096-5100.

20. Whitehead R, VanEeden P, Noble M, et al. (1993) Establishment of conditionally immortalized epithelial cell lines from both colon and small intestine of adult H-2Kb-tsA58 transgenic mice. Proc Natl Acad Sci U S A 90, 587-591.

21. Fenton J, Hord N, Lavigne J, et al. (2005) Leptin, insulinlike growth factor-1, and insulin-like growth factor- 2 are mitogens in $\mathrm{APC}^{\mathrm{min} /+}$ but not $\mathrm{APC}^{+/+}$colonic epithelial cell lines. Cancer Epidemiol Biomarkers Prev 14, 1646-1652.

22. Mosmann T (1983) Rapid colorimetric assay for cellular growth and survival: application to proliferation and cytotoxicity assays. J Immunol Methods 65, 55-63.

23. Darzynkiewicz Z \& Huang X (2004) Analysis of cellular DNA content by flow cytometry. Curr Protoc Immunol 60, 5.7.1-5.7.18.

24. Fenech M (2007) Cytokinesis-block micronucleus cytome assay. Nat Protoc 2, 1084-1104.
25. O'Callaghan N, Dhillon V, Thomas P, et al. (2008) A quantitative real-time PCR method for absolute telomere length. Biotechniques 44, 807-809.

26. Livak K \& Schmittgen T (2001) Analysis of relative gene expression data using real-time quantitative PCR and the $2^{-\Delta \Delta \mathrm{CT}}$ method. Methods 25, 402-408.

27. Krick R, Mühe Y, Prick T, et al. (2009) Piecemeal microautophagy of the nucleus: genetic and morphological traits. Autophagy 5, 270-272.

28. González-Sarrías A, Li L \& Seeram N (2011) Effects of maple (Acer) plant part extracts on proliferation, apoptosis and cell cycle arrest of human tumorigenic and non-tumorigenic colon cells. Phytother Res 26, 995-1002.

29. Kundu JK \& Surh Y-J (2008) Cancer chemopreventive and therapeutic potential of resveratrol: mechanistic perspectives. Cancer Lett 269, 243-261.

30. Ling Y, el-Naggar A, Priebe W, et al. (1996) Cell cycle dependent cytotoxicity, G2-M phase arrest, and distribution of $\mathrm{p} 34 \mathrm{cdc} / \mathrm{cyclin} \mathrm{B} 1$ activity induced by doxorubicin in synchronized p388 cells. Mol Pharmacol 49, 832-841.

31. Blackburn E (1992) Telomerases. Annu Rev Biochem 61, 113-129.

32. Ramachandran C, Fonseca H, Jhabvala P, et al. (2002) Curcumin inhibits telomerase activity through human telomerase reverse transcritpase in MCF-7 breast cancer cell line Cancer Lett 184, 1-6.

33. Boklan J, Nanjangud G, MacKenzie K, et al. (2002) Limited proliferation and telomere dysfunction following telomerase inhibition in immortal murine fibroblasts. Cancer Res $\mathbf{6 2}$, 2104-2114.

34. Harley C, Futcherand A \& Greider C (1990) Telomeres shorten during ageing of human fibroblasts. Nature (Lond) 345, 458-460

35. Lant B \& Storey K (2010) An overview of stress response and hypometabolic strategies in Caenorhabditis elegans: conserved and contrasting signals with the mammalian system. Int J Biol Sci 6, 9-50.

36. Morselli E, Mariño G, Bennetzen M, et al. (2011) Spermidine and resveratrol induce autophagy by distinct pathways converging on the acetylproteome. J Cell Biol 192, 615-629.

37. Cohen H, Miller C, Bitterman K, et al. (2004) Calorie restriction promotes mammalian cell survival by inducing the SIRT1 deacetylase. Science 305, 390-392.

38. Lee I, Cao L, Mostoslavsky R, et al. (2008) A role for the NAD-dependent deacetylase Sirt1 in the regulation of autophagy. Proc Natl Acad Sci US A 105, 3374-3379.

39. Akare S, Jean-Louis S, Chen W, et al. (2006) Ursodeoxycholic acid modulates histone acetylation and induces differentiation and senescence. Int J Cancer 119, 2958-2969.

40. Bandyopadhyay D \& Medrano E (2003) The emerging role of epigenetics in cellular and organismal aging. Exp Gerontol 38, 1299-1307.

41. Fenech M, Kirsch-Volders M, Natarajan A, et al. (2011) Molecular mechanisms of micronucleus, nucleoplasmic bridge and nuclear bud formation in mammalian and human cells. Mutagenesis 26, 125-132.

42. Shimizu N, Shimuara T \& Tanaka T (2000) Selective elimination of acentric double minutes from cancer cells through the extrusion of micronuclei. Mutat Res 448, 81-90.

43. Shimizu N, Kanda T \& Wahl GM (1996) Selective capture of acentric fragments by micronuclei provides a rapid method for purifying extrachromosomally amplified DNA. Nat Genet 12, 65-71. 